\title{
Interactive comment on "Investigation of water adsorption and hygroscopicity of atmospheric particles using a commercial vapor sorption analyzer" by Wenjun Gu et al.
}

Wenjun Gu et al.

mingjintang@gig.ac.cn

Received and published: 7 September 2017

The comment was uploaded in the form of a supplement:

https://www.atmos-meas-tech-discuss.net/amt-2017-56/amt-2017-56-AC3-

supplement.pdf

Interactive comment on Atmos. Meas. Tech. Discuss., doi:10.5194/amt-2017-56, 2017. 